\title{
Biometric analysis of Lepidocyclina (Nephrolepidina) from Baba Formation (Late Oligocene) in Bai-Hassan Well-25, Kirkuk area, Northeast Iraq
}

\author{
Imad Mahmood Ghafor \\ Department of Geology School of Science, Faculty of Science and Scientific Education, Sulaimani University-Iraqi Kurdistan Region.
}

\section{Email address:}

drimadgh@yahoo.co.uk

\section{To cite this article:}

Imad Mahmood Ghafor. Biometric Analysis of Lepidocyclina (Nephrolepidina) from Baba Formation (Late Oligocene) in Bai-Hassan Well25, Kirkuk Area, Northeast Iraq. Science Research. Vol. 2, No. 5, 2014, pp. 111-118. doi: 10.11648/j.sr.20140205.16

\begin{abstract}
The investigation is based on a subsurface sequences of bioclastic limestone in Kirkuk area, Northeastern Iraq. These sequences were deposited in a shallow open marine environment during Late Oligocene. Tests of larger foraminifera Lepidocyclina(Nephrolepidina) are abundant in the lower and upper parts of the Baba Formation. Biometric investigations of the Megalospheric forms of Nephrolepidina assemblages from, Bai-Hassan well- 25 section led to recognize three morphometrically defined species by the combination of three parameters, 1 - the degree of embracement of the protoconch by the deuteroconch (Factor A), 2- the numbers of accessory auxiliary chambers on the deuteroconch (Factor B), and 3- (Factor C ) which expressed by the protoconch angle $(\boldsymbol{\alpha})$ formed by the two hypothetical line from the center of protoconch throught the outer attachment points of the deuteroconch walls with protoconch.
\end{abstract}

Keywords: Late Oligocene, Kirkuk Area, Northeast Iraq, Bai-Hassan Well-25, Biometric Analysis

\section{Introduction}

The genus Lepidocyclina Douvillé, classified by Cole (1938) but reviewed by Adams, 1987, he emphasizes the characteristics of well differentiated megalospheric test and special importance is attached to the embryonic apparatus and periembryonic chambers since these are least likely to have been affected by abnormal environmental conditions during life, is usually divided into a number of subgenera, In the Indo-Pacific province, there are three common subgenera Lepidocyclina (Lepidocyclina), Lepidocyclina (Eulepidina) and Lepidocyclina (Nephrolepidina), as early as 1936-1937, Tan Sin Hok was the first to emphasize the importance of periembryonic chambers for the classification and evolutionary trends in Lepidocyclina, but it was Van der Vlerk (1957, 1959, 1963, 1974) who introduced numerical methods by defining a number of parameters in the classification of Lepidocyclina.

The principle of nepionic acceleration was tested in the succession European

Lepidocyclinidae by Drooger and Freudenthal (1964), Freudenth(1966),Meulenkamp

and Amato (1972), Geerates, (1983), Drooger and Lagland,
(1986),Drooger, (1993) using numerical methods, Ghafor (2004), these studies supported the idea of more than one pattern of evolution in the group.

By now the subgenus Lepidocyclina(Nephrolepidina) is found in the bioclastic

limestone of Late Oligocene age, in the Bai-Hassan well 25, (Fig. 1)

During the last years, the importance of

Nephrolepidina assemblage has become more importance in Iraqian stratigraphy

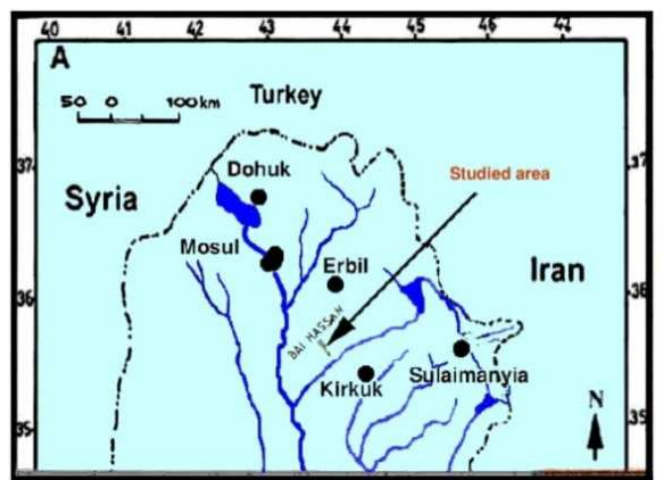

Fig (1). Location map of the Studied Well. 


\section{Previous Research on Lepidocyclinidae}

A large number of studies classified Lepidocyclina in depending upon the morphological features : Douville (1898), Van der Vlerk $(1924,1929)$ and Cole (1938).

Tan Sin Hok (1936) was first to emphasize the importance of peri-embryonic chambers, for the classification of Lepidocyclinid assemblages, showed a time related increase the degree to which the protoconch is embraced by the deuteroconch and an increase in the number of chambers found directly from the deuteroconch (ad-auxiliary chambers).

Publication about European material are from Drooger and Freudenthal (1964), Freudenthal(1966), De Molder (1975), Geerates (1983), Drooger(1993) subdivided the European Nephrolepidina into three successive species with species boundaries based on means values of $\mathrm{C}$ and $\mathrm{A}$.

Adam (1987) subdivided Nephrolepidina into three subgenera on the nature and arrangement of their pereiembryonic chambers,

In European -Mediterranean area, An a single phylogenitic lineage showing different evolutionary velocity on the basis of combination of two parameters, the degree of embracement of the protoconch by the deuteroconch (factor A) and the number of accessory auxiliary chambers on the deuteroconch (Factor C) discussed by (Drooger and Rohling1988), The morphometric of Lepidocyclina argued from Kutch, India by many micropaleontologists of India mentioned the occurrence of Lepidocyclina following different typological species concepts (Saraswati, 1995, Sartaswati and ArunKumar, 2000, Muthukrishnan and Saraswati, 2001).

In Iraq the occurrence of Lepidocyclina thoroughly was recorded in different oilfields in north and northwest of Iraq by Mohammad, 1983, Al-Hashimi and Amer, 1985. Hadad, 1991, El-Esia, 1992, Abid, 1997, Al-Gburi , El-Esia, 2002 and Ghafor(2004).

\section{Materials and Methods of Investigation}

\subsection{Data Gathering}

The occurrence of (Lepidocyclina) is typically associated with shallow water carbonate sediment Baba Formation and the facies change typically evolved in this environment, so that it is seldom to find typical Oligocene carbonates (Baba Formation) in the studied area, therefore the sampling is carried out from subsurface section of Bai-Hassan well25 section, led to a firmer placement of larger foraminifera Lepidocyclinia (Nephrolepidina), Baba Formation.

\section{Microfacies}

Oligocene Baba Formation in Bai-Hassan Well-25, subdivided into three microfacies (, which are the following from the lower part to the upper part of the section. :-
Microfacies I: It consist of larger Foraminiferal packstone.

The lower most interval of this section, characterized by presence of larger foraminifera with Mollusca and Algae bioclastic facies of about (26 meter) thick, which show general fining upwards, which shows deepening, the relative frequency of the planktonic foraminifera in association with smaller foraminifera, is variable with a peak values of 55 percent, The coarse fraction of the packstone is dominated by larger foraminifera, echnoid and algal bioclasts, especially the later which in most cases are of the Melobesioid type, which is generally has a subrounded shape. The ratio of $\mathrm{P}(\mathrm{P}+\mathrm{B})$ is high which indicate that the sediment were deposited on a relatively shallow, open marine slope or platform.

Microfacies II: It consist of smaller foraminiferal packstone

The thickness of this facies is about ( 25 meters ), which consists of vaguely bedded, fine and medium grain packstone, in which larger bioclasts are very rare, Bioturbation is the most frequently observable sedimentary structure, small scale burrows, the previous facies is marked by an increase of the grain size above this facies and generally fining upwards coarse to medium packstone.

Microfacies III: It consist of fine bioclasts with smaller foraminiferal wackstone

\begin{tabular}{|c|c|c|c|c|}
\hline \multicolumn{2}{|c|}{ Age $\quad$ Facies } & \multirow{2}{*}{$\begin{array}{c}\begin{array}{c}\text { Reef / Back } \\
\text { reef }\end{array} \\
\qquad \text { Anah }\end{array}$} & \multirow{2}{*}{$\begin{array}{c}\text { Fore Reef } \\
\text { Azkand }\end{array}$} & \multirow{2}{*}{$\begin{array}{c}\text { Off-Shore } \\
\text { Ibrahim }\end{array}$} \\
\hline 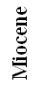 & Aquitanian & & & \\
\hline \multirow{2}{*}{ 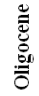 } & Chattian & Bajawan & Baba & Tarjil \\
\hline & Rupelian & Shurau & Sheikh Alas & Palani \\
\hline
\end{tabular}

Fig (2). Lithostratigraphic units of Kirkuk Group subdivisions is based on age, facies and the relationships between reef /back reef, fore reef and offfore facies ,( Modified from Bellen., 1956)

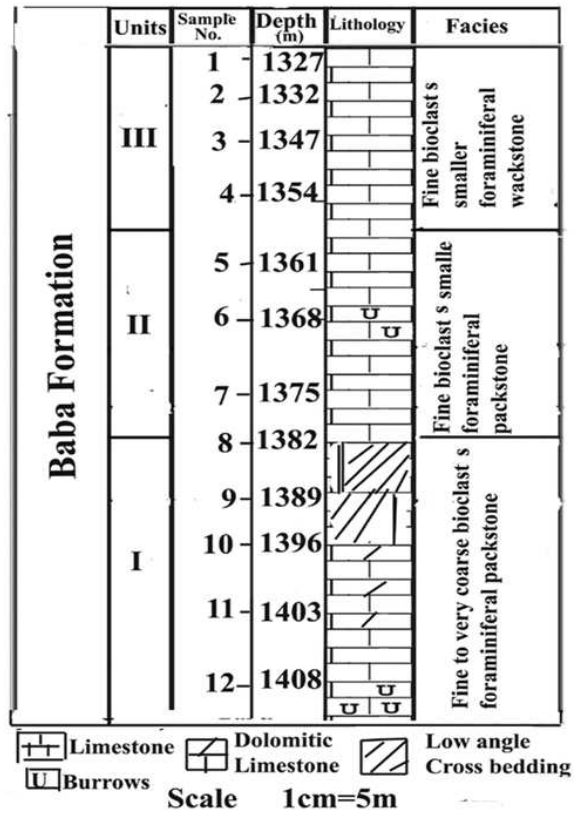

Fig (3). Lithostratigraphic column of the section in Bai-Hassan Well-25. 
The thickness of this unit is a bout (30 meters), in which it's lower part are dolomitized and associated with high frequency of badly preserved Lepidocyclina. The lower part is dolomitized too.Figs. (2,3).

\subsection{Biometric Parameters of Lepidocyclina (Nephrolepidina)}

Drooger (1993) introduce a number of counts and measurements for Lepidocyclina(Nephrolepidina). Only a few characteristic parameters that define species are considered in this paper, In Figures (4.a, b ) show the internal features on which counts and measurements in median sections of Lepidocyclina(Nephrolepidina) specimens are based.

Protoconch: initial chamber (1), deuteroconch: second chamber (2) formed from 1, nucleoconch(embryon): 1 and 2 together.

$P A C$ : Principal auxiliary chamber formed from 2, and resting on 1 and 2.

$A A C I$ : Accessory auxiliary chamber; formed from 1,

$A A C I I$ : ad-auxiliary

chamber formed from 2 .

Embryonic stage: Consists in our Lepidocyclina forms of all chambers directly encircling the nucleoconch.( 1 and 2 together)

Neanic stage: All later chambers.

These successive ontogenetic stages are recognized in a single plane of growth, called the median or equatorial layer. The parameters are:

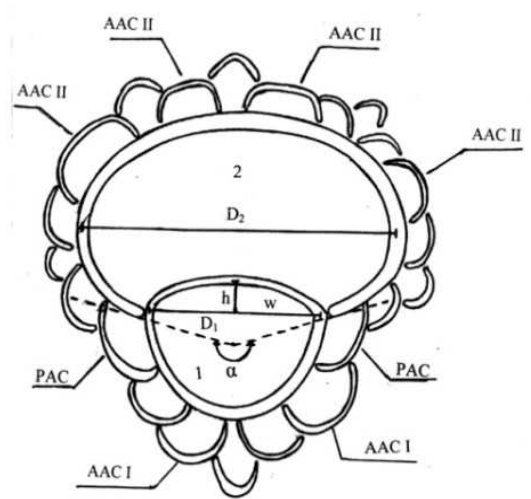

(a)

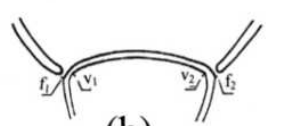

(b)

Fig (4). a- Schematic drawing showing the methods of measuring and count-ing the internal features in Nephrolepidina. $b$-Methods of measureing the degree of embracement in the embryonic chambers, $A_{i}$, the length of common wall is measured from $v_{1}$ to $v_{2}, A_{o}$ from $f_{1}$ to $f_{2}$ (after De Mulder, 1975 and Drooger, 1993).

$A_{i}$ : Degree of embracement of the protoconch (1) by the deuteroconch (2).

$$
\mathrm{A}_{\mathrm{i}}=100 \times \frac{\text { Length of common wall between } 1 \text { and } 2}{\text { Total circumference of the protoconh }}
$$

$A_{i}$, is calculated from measurements along the outer wall of the protoconch $\left(\right.$ Fig. $\left.4_{b}, f_{1}-f_{2}\right) ;\left(A_{o}\right)$ from measurements along the inner wall (Fig. $4_{b}, v_{1}-v_{2}$ ).

This is expressed as a percentage, calculated as the ratio of the length of the common wall between 1 and 2, and the total circumference of the protoconch, multiplied by 100; The measurements are done with a line.

$\mathrm{A}_{\mathrm{i}}$ : is calculated from the values obtained along the outer wall of the protoconch, and was introduced by Van Der Vlerk (1959).

Since it is supposed (Drooger \& Freudenthal, 1964, and De Mulder, 1975) that $A_{o}$ and $A_{i}$. differ no more than twice the standard error, also $A$ was calculated, which is $1 / 2\left(A_{0}+A_{i}\right)$, and therefore $(A)$ lies in between $\left(A_{o}\right)$ and $\left(A_{i}\right)$ differs no more than once the standard error of $\left(A_{o}\right)$ and $\left(A_{i}\right)$ each. The difference between $\left(A_{i}\right)$ and $\left(A_{o}\right)$ is relatively small. De Mulder(1975) found that in practice both methods produce the same result.

$\mathrm{C}$ : Number of accessory auxiliary chambers on the deuteroconch (AACII).

$\mathrm{D}_{1}$ : Maximum diameter of the protoconch in $\mu \mathrm{m}$, measured at right angles to line connecting the centers of 1 and 2. Half of the thickness of the wall is included. $D_{2}$ : maximum diameter of the deuteroconch, measured at right angles to the connection line between the centers of 1 and 2 . Also in $\left(D_{2}\right)$ values, half of the thickness of the wall is included.

$\mathrm{D}_{2} / \mathrm{D}_{1}$ : reflects the relative size of both embryonic chambers.

$\mathrm{R}$ : degree of curvature, calculated from the formula:- $\mathrm{R}=$ $100 \mathrm{~h} / \mathrm{w}$. In this equation (w) is taken along the line connecting the attachment points of the deuteroconch to protoconch. Generally, (w) and (h) are measured along the maximum height of the protoconch that is inclosed by the deuoteroconch, measured at right angle to $\mathrm{w}$.

$\alpha$ : It reflects the degree of embracement of the protoconch by the deuteroconch, expressed by the protoconchal angle which is formed by the two hypothetical line from the center of the protoconch through the outer attachment points of the deuteroconchal walls with the protoconch (Fig4.a.)

\section{Counts and Measurements on the Embryonic - Nepionic Stage and the Relation between Parameters}

(12) samples were subjected to biometric analysis in the studied area. Counts and measurements on the early chambers of Lepidocyclina (Nephrolepidina), were performed according to the procedure described by(Drooger, 1952; Drooger and Freudenthal, 1964; De Mulder, 1975; Drooger and Rohling,1988; Drooger, 1993)) The results of counts and measurements are recorded in tables (1). The names for the morphometrically defined species units have been selected from the older literature, in which a large number of species names were established on a purely 
typological basis and on the basis of characteristics that were never expressed numerically. Especially features of the exterior, such as size and shape of the test and pustules, were used by the earlier authors, such characteristics are considered nowadays to be largely environment-controlled and of subordinate taxonomic value.

In this study the variation in the A-C combination is rather wide along this road causes quite a few ex, intercdetermination as seen as in (Table 1).In section Bai-Hassan well - 25 the units (I,II, and III ) belonged to the Oligocene carbonate (Baba Formation are rich in Lepidocyclina (Nephrolepidina), assemblages which show an increase in the $\left(\mathrm{A}_{\mathrm{i}}\right)$ and $(\mathrm{C})$ values when we introduce from lower to the upper part of these sections.

As seen in the scatter diagrams of the $\left(\mathrm{A}_{\mathrm{i}}-\mathrm{C}, \mathrm{D}_{2}-\mathrm{C}\right.$ and $\mathrm{C}$ $\alpha$ ) are plotted in (Figs. 5,6,7)from the lower part of two 1,Figs. 6,7,8,9. section which show clear visible and strong positive correlation for $\left(\mathrm{A}_{\mathrm{i}}-\mathrm{C}\right),\left(\mathrm{D}_{2}-\mathrm{C}\right)$ and negative correlate for $(\mathrm{C}$ $\alpha)$, the $A_{i}, C$, and $\alpha$ values range between $\left(A_{i}^{-}=35-40, C^{-}=1-3\right.$ and $\alpha>208)$ respectively which have the characteristics of Lepidocyclina (Nephrolepidina),praemarginata. )Plate(1, Figs. 1,2) while their values in the middle part of the two section varies between $\left(\mathrm{A}_{\mathrm{i}}^{-}=39-41, \mathrm{C}^{-}=2-4\right.$

and $\left.\alpha^{-}=199-208\right)$. These assemblages may be classified in the characteristic of Lepidocyclina.ex.interc. praemarginatamorgani, but the samples of the upper part of these sections, Units (III, IV) have strong positive correlate in $\left(\mathrm{A}_{\mathrm{i}}-\mathrm{C}\right),\left(\mathrm{D}_{2^{-}}\right.$ $\mathrm{C})$ relation and negative correlation in $(\mathrm{C}-\alpha)$ relation with values ranging between $\left(\mathrm{A}_{\mathrm{i}}^{-}=40-45, \mathrm{C}^{-}=3-5.25\right.$ and $\alpha^{-}=$ 192,5-199), these assemblages may possess the characteristic of Lepidocyclina (Nephrolepidina)morgani (Table 1 ).Plate

Table (1). Results of Counts and measurements on seven L.(N.) assemblages from the Oligocene Carbonates, (Baba Formation) in Kirkuk well-19 section. M = Mean of the value, $N=$ Number of observation.

\begin{tabular}{|c|c|c|c|c|c|c|c|c|c|c|c|c|}
\hline Series & Stage & Unit & Thickness (m) & $\begin{array}{l}\text { Sample } \\
\text { Number }\end{array}$ & $\mathbf{A}_{\mathrm{i}}^{-}$ & $\mathbf{C}^{-}$ & $\mathrm{D}_{1}^{-}$ & $\mathbf{D}_{2^{-}}$ & $\mathbf{D}_{2} / \mathbf{D}_{1}^{-}$ & $\mathbf{R}^{-}$ & $\boldsymbol{\alpha}^{-}$ & Species \\
\hline \multirow{9}{*}{ 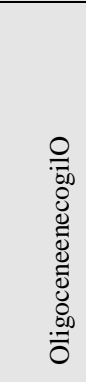 } & \multirow{9}{*}{ 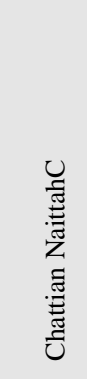 } & \multirow{3}{*}{ III } & \multirow{3}{*}{9} & M20N & 42.513 & 4.9 & 297.3 & 324.6 & 1.09 & 29.4 & 193.9 & L.morgani \\
\hline & & & & M18N & 44.112 & 4.8 & 220.1 & 285.83 & 1.5 & 28.4 & 198.6 & L.morgani \\
\hline & & & & & & & & & & & & L.ex.interc \\
\hline & & \multirow{3}{*}{ II } & \multirow{3}{*}{8} & M16N & 40.710 & 2.9 & 272 & 320.9 & 1.2 & 25.5 & 207.7 & praemarginata- \\
\hline & & & & & & & & & & & & morgani \\
\hline & & & & M14N & 40.812 & 3.5 & 283.3 & 345.8 & 1.2 & 23.5 & 202.5 & $\begin{array}{l}\text { L.ex.interc } \\
\text { praemarginata- } \\
\text { morgani }\end{array}$ \\
\hline & & \multirow{3}{*}{ I } & \multirow{3}{*}{18} & $\mathrm{M} 11 \mathrm{~N}$ & 36.411 & 2 & 260.7 & 298.1 & 1.1 & 17.4 & 239.1 & L.praemarginata \\
\hline & & & & $\mathrm{M} 3 \mathrm{~N}$ & 38.111 & 2.3 & 240.9 & 312.4 & 1.3 & 14.1 & 238.2 & L.praemarginata \\
\hline & & & & M1N & 36.812 & 2.1 & 219 & 315.9 & 1.4 & 5.3 & 238.8 & L.praemarginata \\
\hline
\end{tabular}

The average means of $\left(\mathrm{A}_{\mathrm{i}}-\mathrm{C}\right)$ and $\left(\mathrm{D}_{2}-\mathrm{C}\right)$ shows a positive correlation (Figs.8, 9).while the average means of $\left(\mathrm{C}^{-}-\alpha^{-}\right)$ show a reverse correlation (Fig.10).

In order to support the result, the histogram of $\left(A_{i}\right.$ and $\left.C\right)$ classes are plotted in (Figs11). Which show unimodal and fairly normal distribution pattern for most of the samples The regularity in the $(\mathrm{C})$ histogram might be explained by the lower number of observations. in comparison with wide variation and for the inaccuracies in counting the number of accessory auxiliary chambers . However the wide variation and skewed character of the (C) histogram of the same of the sample may as well be explained by mixing of more primitive and more highly developed assemblages.

There are an unimodal shape of the histogram in both values of $\left(A_{i}\right)$ and $(C)$ which are ranging in both values of $\left(A_{i}\right)$ and $(C)$ which are ranging from (35-40) and (1-3) respectively.

These values corresponds to the Lepidocyclina (Nephrolepidina) praemarginata in the lower part of the two sections, but the samples in the middle part show bimodal shape with values $\left(A_{i}=39-41, C=2-4\right)$ that are related to the species, situated between Lepidocyclina (Nephrolepidina) praemarginata and Lepidocyclina (Nephrolepidina) morgani are named as Lepidocyclina ex. interc. praemarginata morgani, while the upper part of the sections reflect the unimodal shape are close to the characteristics of the Lepidocyclina (Nephrolepidina), morgani.

In Khabaz well-3 and Qarah Chauq Dagh sections, the units (V,VI,VII and VIII) are the subdivision of the sections from the lower to the upper part which are belonged to Late Oligocene-Miocene carbonate (Azkand Formation) , (12) samples from Khabaz well-3 and Qarah chauq Dagh sections, which are rich in Lepidocyclina (Nephrolepidina) individual subjected to biometric analysis, The scatter diagrams of $\left(\mathrm{A}_{\mathrm{i}^{-}}\right.$ $\mathrm{C}), \mathrm{D}_{2}-\mathrm{C}$ ) and $\mathrm{C}-\alpha$ ) are plotted in (Figs 12,13,14) which reveals variable values for $\left(\mathrm{A}_{\mathrm{i}},\right)(\mathrm{C})$ and $\alpha$, between $\left(\mathrm{A}_{\mathrm{i}}^{-}=40\right.$ $45, \mathrm{C}^{-}=5.25$ and $\left.\alpha^{-}=192.5-199\right)$ these value may be referred to Lepidocyclina (Nephrolepidina)morgani (Plate1.Figs. $6,7,8,9)$ ), while the samples from Units (VI,VII) in midpart of the two section have individuals with the values of $\left(\mathrm{A}_{\mathrm{i}},\right)(\mathrm{C})$ and $(\alpha)$ differ from that in the lower part varied between $\mathrm{A}_{\mathrm{i}}^{-}=44-46, \mathrm{C}^{-}=5-5.25$ and $\left.\alpha=189-192,5\right)$ these individuals are situated between Lepidocyclina morgani and Lepidocyclina tournoueri in their character, which is named Lepidocyclina ex. interc .morgani-tournoueri, (Plate.1, Figs 12,13 ), the upper part of these sections Units (VII,VIII) which are known by individuals characterized that the value of $\left(A_{i}\right)$ and $(C)$ have been increased $\left(A_{i}>45\right.$ and $\left.C>5.25\right)$ respectively, but the value of $(\alpha)$ decreased $(\alpha<189.5)$ in addition the relations between $\mathrm{D}_{2}$ and $\mathrm{C}$ and their values 
from same sample may refer to Lepidocyclina. tournoueri (Plate, 1 fig. 14, Table 3,4).

The mean values of $\left(C-A_{i}\right.$ and $\left(D_{2}-C\right)$ shows a distinct positive correlations while the mean values of $(\mathrm{C}-\alpha)$ show a reverse correlation (Figs.15,16.17).

The histogram of $\left(A_{i}\right)$, ( $C$ ) classes (Fig.18) have supported the results which show unimodal and fairly normal distributional pattern for most of the samples.. The samples of the lower part of two sections show the unimodal shape that the values of $\left(\mathrm{A}_{\mathrm{i}}\right)$ and ( $\mathrm{C}$ ) vary between (40-45 and 55.25) respectively, these values are characteristics of the Lepidocyclina morgani while the samples of units (VI,VII) have been revealed bimodal shape these individuals correspond to the L.ex. interc. morgani-tournoueri, but in the upper part the individuals show unimodal shape characterized by the presence of Lepidocyclina. tournoueri (Plate. 1, Fig.14).

Also the means of $\alpha$ show a successive of decreasing values which give indications to the existence of different species of Lepidocyclina (Nephrolepidina) for example the samples of lower of two section belongs to Lepidocyclina morgani which have the mean value of $\alpha$ about (199), while the middle part of the section rep[resented by individual's show clear visible decreasing in the mean value of $(\alpha)$, which range between ( 189.5-192.5) corresponded to Lepidocyclina ex. interc. morgani-tournoueri but the individuals of upper part samples show continuity decreasing in $(\alpha)$ values about $(172,0)$ may refer to Lepidocyclina tournoueri.

Therefore the $\left(A_{i}\right)$ and $(C)$ of these sections in this study corresponds with the range of $\left(\mathrm{A}_{\mathrm{i}}\right)$ and $(\mathrm{C})$ values that mentioned by De Moulder (1975), Drooger, 1993 from different part of the world. In contrast the average degree of curvature of the common wall between the protoconch and deuterocinch ( $\mathrm{R}$ ) has a less regular pattern of increasing values, no clear trend is observed in the average size of protoconch $\left(\mathrm{D}_{1}\right)$ and deuteroconch $\left(\mathrm{D}_{2}\right),\left(\mathrm{D}_{2} / \mathrm{D}_{1}\right)$ values are not actually changing in the lower part of the section (Tables, 1,2 )

\section{Stratigraphic Distribution of Te Biometric Species}

The Oligocene carbonate (Baba Formation) in Bai-Hassan well-25 section subdivided into (I, II, and III ) Units., characterized by the occurrence the first primitive type of Lepidocyclina(Nephrolepidina) praemarginata depending:-

Table(2):- Oligocene carbonate sequence

upon the mean values of the $\left(\mathrm{C}^{-}-\mathrm{A}_{\mathrm{i}}^{-}, \mathrm{C}^{-} \mathrm{D}_{2}^{-}\right.$and $\left.\mathrm{C}^{-}-\alpha^{-}\right)$ relation (Table1). From Unit (II) and lower part of the Unit III which represent the middle part of Baba Formation, Another species is distinguished that situated in their character between Lepidocyclina praemarginata and Lepidocyclina morgani which is represented by Lepidocyclina ex.interc. praemarginata-morgani. The mean values of the $\left(\mathrm{C}^{-}, \mathrm{A}_{\mathrm{i}}^{-}\right)$and $\left(\alpha^{-}\right)$for the individuals from Unit (III). The Lepidocyclina (Nephrolepidina)morgani shows an increase in these parameters in comparing with the previous species, and this species is continued

Whereas in Unit VII, the biometric analysis shows an increasing in the values of $\left(\mathrm{C}, \mathrm{A}_{\mathrm{i}}\right)$ and decreasing the $\left(\alpha^{-}\right)$ values that distinguished another species situated in mide position in their character between Lepidocyclina morgani and Lepidocyclina tournoueri which is named as Lepidocyclina ex.interc .morgani- tournoueri, the lower part of Unit (VII)and Unit (VIII) characterized by the presence of Lepidocyclina (Nephrolepidina) tournoueri which have the highest value of the $\left(C, A_{i}\right)$ and minimum values for the $\left(\alpha^{-}\right)$. (Tables 3 and 4).

Summarizing, it can be stated that mean values of the $(C)$ and $\left(A_{i}\right)$ show successive increasing but the $\left(\alpha^{-}\right)$values decreased from Unit I toward Unit (III), while no clear trend is observed in the average size of protoconch $\left(D_{1}\right)$ and deuteroconch $\left(D_{2}\right)$ from the lower to the upper part of the sequence.

The species are distributed in the Oligocene carbonate sequence based on the mean values of $\left(\mathrm{C}^{-}, \mathrm{A}_{\mathrm{i}}\right.$ and $\left.\alpha^{-}\right)$as the following: Table(2).

Table(2). The species are distributed in the Oligocene carbonate sequence based on the mean values of $\left(C^{-}, A_{i}\right.$ and $\left.\alpha^{-}\right)$

\begin{tabular}{llll}
\hline Species & $\mathbf{A}_{\mathbf{i}}^{-}$ & $\mathbf{C}^{-}$ & $\boldsymbol{\alpha}^{-}$ \\
\hline L.tournoueri & $\mathrm{A}_{\mathrm{i}}^{-}>45$ & $\mathrm{C}^{-}>5.25$ & $\alpha^{-}<189.5$ \\
L. ex.interc.morgani-tournoueri & $44<\mathrm{A}_{\mathrm{i}}^{-}<46$ & $5<\mathrm{C}^{-}<5.5$ & $189.5<\alpha^{-}<192.5$ \\
L.morgani & $40, \mathrm{~A}-\mathrm{i}<45$ & $3<\mathrm{C}^{-}<5.25$ & $192.5<\alpha^{-}<199$ \\
L.ex.interc. praemarginata-morgani & $39<\mathrm{A}^{-} \mathrm{i}<41$ & $2<\mathrm{C}^{-}<4$ & $199<\alpha^{-<208}$ \\
L.praemarginata & $35<\mathrm{A}^{-} \mathrm{i}<40$ & $1<\mathrm{C}^{-}<3$ & $208<\alpha^{-}$ \\
\hline
\end{tabular}

The species of Nephrolepidina are distributed from the lower part of the Unit (I) of the Baba Formation, to the Unit (III) of the upper part of the Azkand Formation. Table (3) .

Table (3). Stratigraphic distribution of L.(N.) spp. in the studied area.

\begin{tabular}{|c|c|c|c|}
\hline Series & Stage & Unit & Species/Lepidocyclina(Nephrolepidina)/L.ex. interc. \\
\hline \multirow{5}{*}{ Oligocene } & \multirow{5}{*}{ Chattian } & \multirow{2}{*}{ III } & L.(N.) tournoueri \\
\hline & & & L. ex. interc. morgani-tournoueri \\
\hline & & \multirow{2}{*}{ II } & L. ex. interc. morgani-tournoueri \\
\hline & & & L. ex. interc. praemarginata-morgani \\
\hline & & I & L.morgani \\
\hline
\end{tabular}




\section{Conclusions}

Morphometric of Lepidocyclina (Nephrolepidina) were distinguished by using biometric analysis of Lepidocyclina (Nephrolepidina) individuals, based on the mean values of $\left(\mathrm{C}, \mathrm{A}_{\mathrm{i}}\right.$ and $\alpha$ )

In this study the variation in the $(\mathrm{A}-\mathrm{C})$ combination is rather wide along this road causes quite a few ex. interc. determinations represented by Lepidocyclina (Nephrolepidina) ex. interc praemarginata-morgani, Lepidocyclina (Nephrolepidina) ex. interc. morganitournoueri.

\section{Plate(1)}

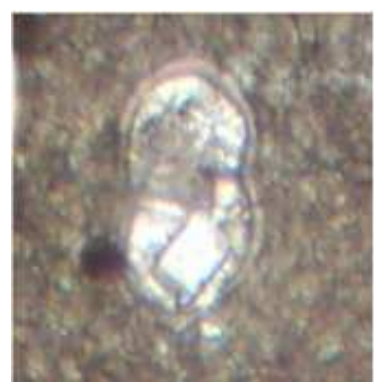

Fig. (1). Lepidocyclina (Nephrolepidina) praemarginata, Unit (I),sample(1), Kirkuk well-19 section, Baba Formation, oriented section, (40X).

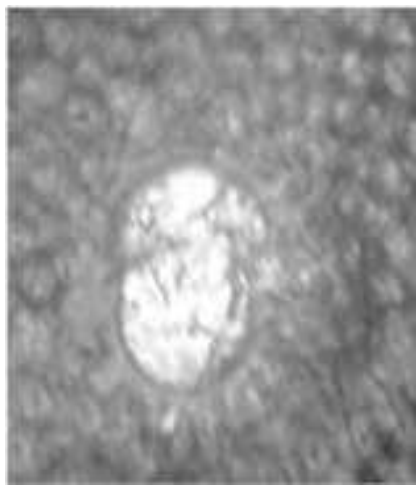

Fig. (2). Lepidocyclina (Nephrolepidina) praemarginata, Unit (II), sample (16), Bai-Hassan well-4 section, Baba Formation, oriented section (40X)

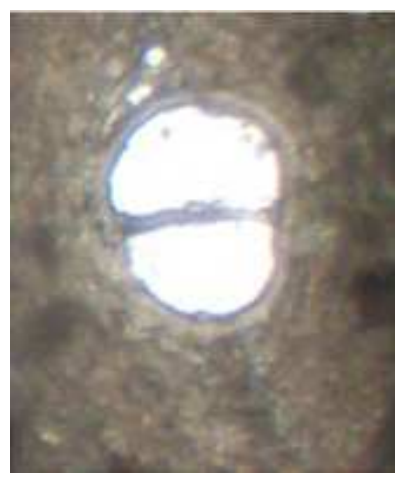

Fig. (3). Lepidocyclina (Nephrolepidina) ex. interc. praemarginata-morgani Unit (III), samples (18), Bai-Hassan well-4 section, Baba Formation, oriented section (40X).

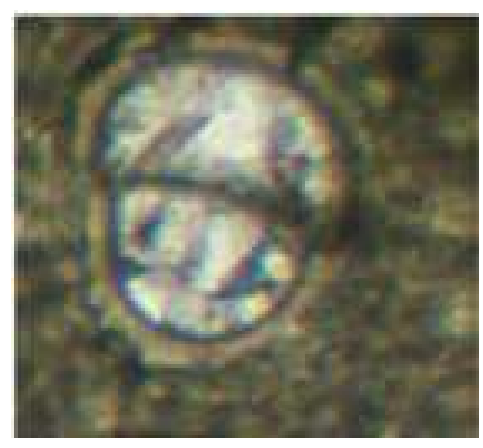

Fig. (4). Lepidocyclina (Nephrolepidina) ex. interc. praemarginata-morgani Unit(II), sample (19), Bai-Hassan well-4 section, Baba formation, (40X) Kirkuk well-19 section, Baba Formation, oriented section (40X).

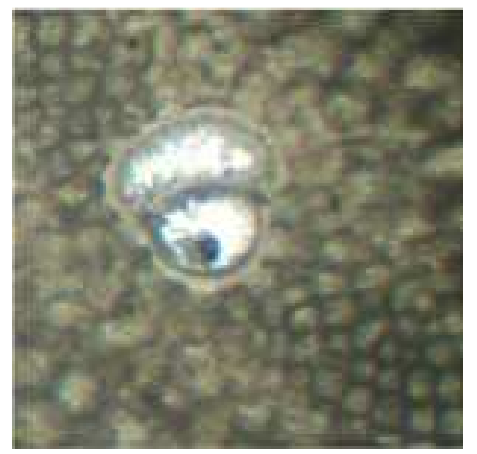

Fig. (5). Lepidocyclina (Nephrolepidina) ex. interc. praemarginata-morgani Unit II),sample (18), Bai-Hassan well-4 section, Baba Formation, oriented section (35X).

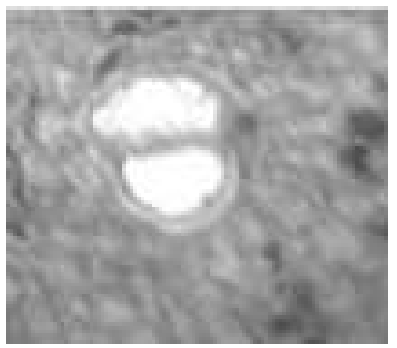

Fig. (6). Lepidocyclina (Nephrolepidina) morgani,Unit (IV), sample(23) Bai-Hassan well-4 section, Baba Formation. oriented section (30X)

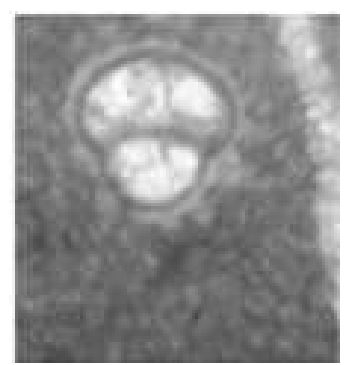

Fig. (7). Lepidocyclina (Nephrolepidina) morgani,Unit (II), sample(22) BaiHassan well-4 section, Baba Formation. oriented section (35X) 


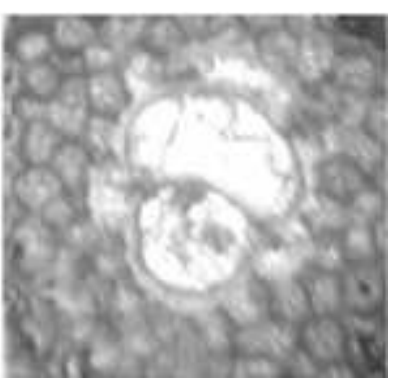

Fig. (8). Lepidocyclina (Nephrolepidina) morgani Unit(VII),sample (18), Qarah chauq Dagh section, Azkand Formation. oriented section (40X)

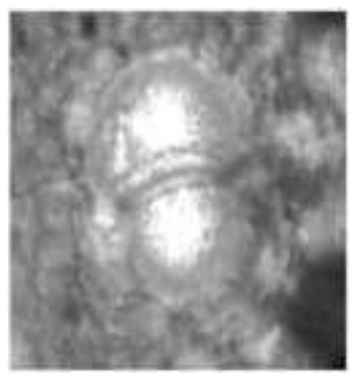

Fig. (9). Lepidocyclina (Nephrolepidina) morgani,Unit (VII),sample(18) Qarah chauq Dagh section, Azkand Formation. oriented section (30X)

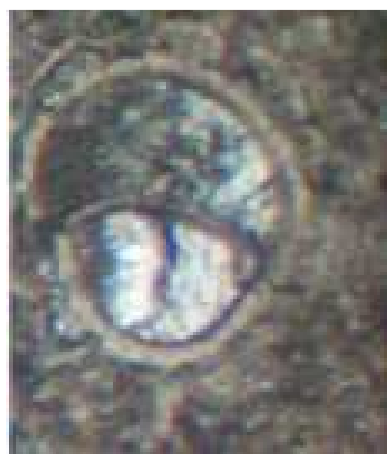

Fig. (10). Lepidocyclina (Nephrolepidina) ex. interc. morgani tournoueri Unit (VI),sample(28), Khabaz well-3 section, Azkand Formation. oriented section (40X).

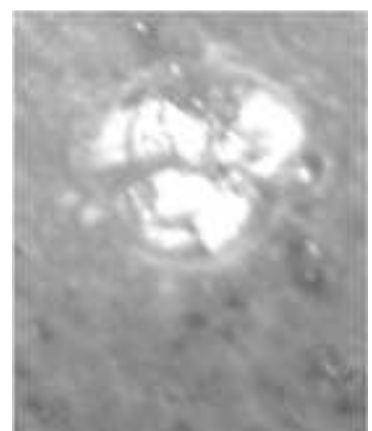

Fig. (11). Lepidocyclina (Nephrolepidina) tournoueri Unit (VIII),sample(26) Qarah chauq Dagh section, Azkand Formation. oriented section (35X)

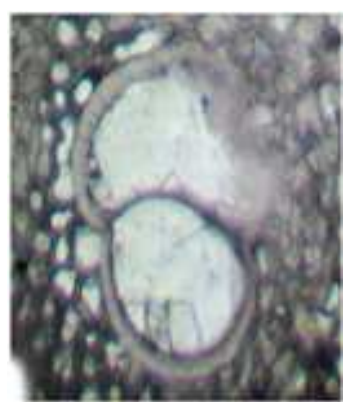

Fig. (12). Lepidocyclina (Nephrolepidina) ex. interc. morgani tournoueri, Unit (VII) sample(35), Khabaz well-3 section, Azkand Formation. oriented section, (40X)

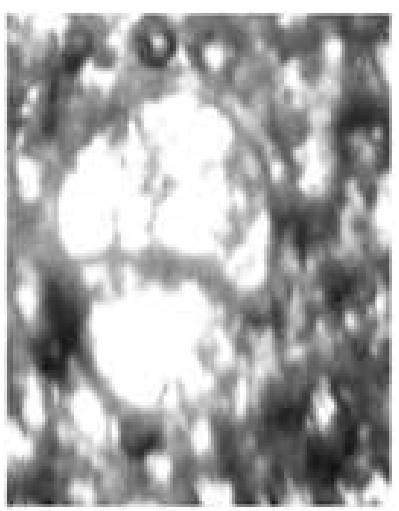

Fig. (13). Lepidocyclina (Nephrolepidina) ex. interc. morgani tournoueri, Unit (VII), sample (35), Khabaz well-3 section, Azkand Formation. oriented section, $(40 X)$

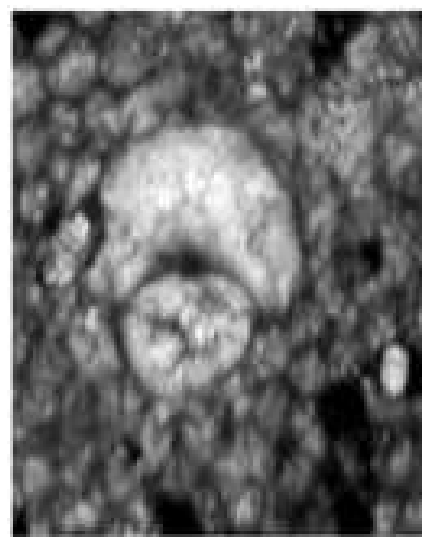

Fig. (14). Lepidocyclina (Nephrolepidina) tournoueri, Unit (VII), sample(42),Khabaz Well-3 section, Azkand Formation, oriented section (40X).

\section{References}

[1] Abid, A, A.(1997). Biostratigraphy and Microfacies of the Late Oligocene-Miocene formations center and north Iraq. (Unpublished) Ph.D. Thesis, Coll. Of Sci. Baghdad Univ., 258p. (In Arabic)

[2] Adams, C. G. (1987). On the classification of the Lepidocyclinidae (Foraminifera) with re-description of the unrelated Paleocene genera Actinosiphon and Orbitosiphon. Micropaleontology, vol. 33, no.4, pp.289-317, pls. 1-4. 
[3] Al-Guburi, H. M. Q; and El-Esa, R. M. (2002). The stratigraphy and depositional environment of Paleogene Lower Neogene subsurface sequence in the area between BaiHassan and Al-Qayarah oil fields. 5th Iraqi Geological Congress, Baghdad.

[4] Al-Hashimi, H. A. J.; and Amer, R.M. (1985) . Tertiary Microfacies of Iraq. D.G. geol. Surv. Min. Invest. Puli., Baghdad, 56pp, 17figs., 159pls. (S.O.M.).

[5] Cole, W. S., (1938): Stratigraphy and Micropaleontology of two deep wells in Florida. Florida Geol. Surv., Bull., vol. 16, pp. 1-73.

[6] De Mulder, E. F. J. (1975). Microphona and sedimentary tectonic history of the Oligo- Miocene of the Joniane Islamnd and Western Europe (Greece). Ulrecht. Micropal. Bull., vol. 13, 140.pp.

[7] Douvillé, H. . (1898). Sur I'age des couches traverse/es par le canal du Panama. Soc. Ge/ol. France, Bull.; vol.3, 26, pp. 587-600.

[8] Drooger, C. W. (1952). Study of American Miogypsinidae. Thesis Univ.Utrecht, p. 1-80.

[9] Drooger, C. W. (1993). Radial Foraminifera Morphometrics and Evolution, verhamd, Kon. Ned. Akad. Wetensch. Amesterdam, pp. 1-241.

[10] Drooger, C. W. and Freudenthal, Th. (1964). Associations of Miogypsina and Lepidocyclina at some European localities. Ecl. Geol. Helv.; vol. 57; pp. 509- 528.

[11] Drooger, C. W.; and Laagland, H.,M (1986). Larger Foraminiferal zonation of the Europian-Mediteeriane Oligocene. Proc. Kon. Ned. Akad. Wet., ser. B, vol. 189, pp. 135-148.

[12] Drooger, C. W.; and Rohling E. j. (1988). Lepidocylina migration across the Atlantic, Jou. of Paleontology , Procceedings loninklijike Nederlandse Academie van wetenschappen, (B), vol. 91: pp. 39-52.

[13] El-Eisa, M. E. S. (1992). Coral reef of Late Oligocene-early Miocene, Kirkuk and surrounding area. Iraqi. Geol. Jour. vol.(25), no. 2, Issued, pp. 17-32. (In Arabic)

[14] Freudenthal, Th. (1966). Nephrolepidina at some classical European localities. Proc. 3rd. Sess. Comm. Med. Neog. Strat., Berne 1964, pp.55-57. Brill, Leiden.

[15] Geerates, W., (1983). Biometrical analysis of early middle Oligocene Nephrolepidina praemarginata and Heterostegina sp. Associations from Villajoyosa, SE.Spain Intern. Rep. dept. stratigraphy state Univ. Utrecht. 91 pages.

[16] Hadad, N. H. (1991). Biostratigrapgic studies for the Tertiary Formations in some

[17] oilfields, in the area of N.O.C. Kirkuk Office, unpublished (In Arabic).

[18] Mohammed, Q. A. (1983). Biostratigraphy of Kirkuk Group in Kirkuk and Bai-Hassan areas, Unpublish. M.Sc. Thesis, coll. Sci. Univ. of Baghdad.

[19] Mulenkamp, J. E.; and Amato, V. (1972). Cycloclypeus and Nephrolepidina from the Oligocene of mollero (N. Italy). Id., (B); 75, pp. 34-47

[20] Muthukrishnan, S.; and Saraswati, P. K. (2001). Shape analysis of the nucleoconch of Lepidocyclina from Kutchataxonomic interpretation. Micropaleontology, vol. (47), no. 1, pp. 87-92, text figures, 1-33, plates 1.

[21] Saraswati, P. K. (1995)' Biometry of early Oligocene Lepidocyclina from Kutch, India. Marine Micropal. vol. (20), pp. 303-311.

[22] Saraswati, P. K.; and Kumar, A. (2000). Morphometrics of some Lepidocyclina Foraminifera: applications in Taxonomy and Biostratigraphy. Geological data analysis: statistical methods. Hindistan publishing corporation (India) New Delhi. pp. 63-70, Figs. 6.

[23] Tan Sin Hok. (1936a).Zur Kenntnis der Miogypsiniden. De Ingenieur in Ned. Indië, Jaarg. 3, no. 3, pp. 45-61. no.5, pp. 84-98, no. 7, pp. 109-123.

[24] Vlerk, Van der I.M, (1929).Groote Foraminiferen van NoordOost borneo. Id., vol. (9), p. 5-44.

[25] Van Der Vlerk, I.M, (1957). Des Stratigrafische betekensis van het "genus Lepidocyclina". Proc. Kon. Ned. Akad. Wet., (B); vol. (66), pp. 23-27.

[26] Vlerk, Van der I.M, (1959a). Modification de I'ontogénése pendant I'évolution des Lépedocyclines (Foraminifers). Soc. Géol. France, bull. (7); vol. (1), p. 669-673.

[27] Vlerk, Van der I.M, (1959b). Problems and principles of Tertiary and Quaternary stratigraphy. Geol. London, Quart. Journ:., 115, pp. 49-63.

[28] Vlerk, Van der I.M, (1963).Biometrical research on Lepidocyclina. Micropal. vol. (9), pp. 425-426.

[29] Vlerk, Van der I.M, (1974). Nomenclatural and numerical taxonomy (names and numbers). Verhandi. Naturf. Ges. Basel; vol. (84), pp. 245-255. 